\title{
The effect of epidermal growth factor and IGF-I infusion on hepatic and renal expression of the IGF-system in adult female rats
}

\author{
J W van Neck, E M Berghout, L Vinter-Jensen ${ }^{1}$, C A H Groffen, \\ V Cingel, N F J Dits, S L S Drop and A Flyvbjerg ${ }^{2}$
}

\author{
Laboratory of Pediatrics, Subdivision of Pediatric Endocrinology, Erasmus University/Sophia Children's Hospital, Rotterdam, The Netherlands \\ ${ }^{1}$ Department of Clinical Biochemistry, Aarhus University Hospital, Aarhus, Denmark \\ ${ }^{2}$ Medical Research Laboratories, Institute of Experimental Clinical Research, Aarhus University Hospital, Aarhus, Denmark \\ (Requests for offprints should be addressed to J W van Neck, Laboratory for Pediatrics, Room Ee1500, Erasmus University Rotterdam, PO Box 1738, \\ 3000 DR Rotterdam, The Netherlands; Email: vanneck@kgk.fgg.eur.nl)
}

\begin{abstract}
Systemic administration of epidermal growth factor (EGF) in neonatal rats results in reduced body weight gain and decreased circulating levels of IGF-I, suggesting its involvement in EGF-induced growth retardation.

We investigated the effect of EGF and/or IGF-I administration for 7 days on circulating IGF-I and IGFBP levels and hepatic and renal IGF-system mRNA expression profiles in adult female rats. EGF administration $(30 \mu \mathrm{g} / \mathrm{rat} / \mathrm{day})$ did not influence body weight, liver or kidney weight. In contrast, IGF-I $(400 \mu \mathrm{g} / \mathrm{rat} /$ day $)$ and EGF/IGF-I administration increased both body weight and kidney weight. Also, serum IGF-I and the $30 \mathrm{kDa}$ IGFBPs (IGFBP-1 and -2) were significantly increased in these groups. Serum IGFBP-3 levels increased in the IGF-I group along with increased hepatic IGFBP-1 and -3 mRNA levels. In contrast, in the EGF administration group serum IGFBP-3 levels were significantly decreased;
\end{abstract}

however, the mRNA levels remained unchanged. In the EGF/IGF-I administration group, serum IGF-I and IGFBP-3 levels were significantly lowered when compared with the IGF-I administration group. This was in contrast to the effect on kidney weight increase that was identical for the IGF-I and EGF/IGF-I groups. The decrease in serum IGFBP-3 was not reflected at the hepatic IGFBP-3 mRNA level. IGFBP-3 expression might be regulated at a post-transcriptional level although EGF induced IGFBP-3 proteolysis could not be demonstrated in vitro.

We conclude that EGF administration reduced serum IGFBP-3 whereas IGF-I administration increased the level of IGFBP-3 and IGF-I and resulted in an increased body and kidney weight in adult female rats.

Journal of Endocrinology (2000) 165, 115-122

\section{Introduction}

Insulin-like growth factor I (IGF-I) is a multifunctional growth factor produced in a variety of body fluids and tissues including liver and kidney. IGF-I is a member of the IGF-system that also consists of IGF-II, two types of IGF receptor and six different IGF binding proteins (IGFBPs) (Kelley et al. 1996). Furthermore, four IGFBP related proteins have been described (Baxter et al. 1998). The IGFBPs are abundantly present in the circulation, organs and tissues and act as major modulators of IGF action by transporting the IGFs to their sites of action and controlling the bioavailability of the IGFs to their surface receptors (Kelley et al. 1996). However, little is known about the in vivo regulation of their production.

The epidermal growth factor (EGF) belongs to a family of growth factors that regulate cell proliferation, migration and differentiation through binding to receptor tyrosine kinases on target cells (Miettinen 1997). EGF has been shown to act as a mitogen as well as a differentiation factor for many cell types (Bonassar \& Trippel 1997). It is present in the circulation at very low concentrations that, nevertheless, also elicit cellular responses in vitro (Bujia et al. 1993, Murakami et al. 1994). In addition, the kidney is thought to be the major site of EGF synthesis in mammals (Fisher et al. 1989).

Given the large number of hormones, cytokines and growth factors present in the circulation, organs and tissues, interactions between growth factor families are a field of growing interest. Several studies have focused on the interaction between the EGF and IGF systems in vitro. EGF addition to isolated rat renal collecting duct cells increased IGF-I mRNA levels 3-fold (Rogers et al. 1991). EGF addition to human keratinocytes in primary culture reduced IGFBP-3 mRNA levels to $50 \%$ of control values whereas IGF-I addition had no effect (Edmondson et al. 1999). Furthermore, addition of EGF to rat hepatocytes in primary culture had a dose-dependent stimulatory effect 
on IGF-I and IGFBP-1 production (Barreca et al. 1992). Accordingly, IGF-I modulates the EGF receptor action in keratinocyte proliferation (Krane et al. 1991), whereas EGF stimulates IGF-I biosynthesis in the liver and in the kidneys. However, only a few studies have examined these interactions during systemic administration in vivo (Frystyk et al. 1996, Vinter-Jensen et al. 1996).

In the present paper we investigated the effects of short term (7 days) EGF and/or IGF-I administration on the expression of the circulating, hepatic and renal IGF-system genes in young adult female rats.

\section{Materials and Methods}

Animals

Female Wistar rats (mean body weight $190 \mathrm{~g}$ ) obtained from our own breeders (Department of Pathology, Aalborg Hospital, Denmark) were used in the study. The animals were housed individually in cages on white special spanwall bedding. They were fed a standard laboratory diet (No. 1310, Lage, Germany), had free access to water and were kept at constant temperature $\left(21^{\circ} \mathrm{C}\right)$, humidity $(55 \pm 5 \%)$ and at a ratio of 12-h light: $12-\mathrm{h}$ darkness cycle (0600-1800 h light). The study complied with Danish regulations for care and use of laboratory animals.

\section{Study design}

The rats were randomly allocated into four groups of eight animals:

(1) Placebo control: animals infused with $0 \cdot 1 \mathrm{M}$ acetic acid.

(2) EGF group: animals infused with $30 \mu \mathrm{g} / \mathrm{rat} / \mathrm{day}$ human recombinant (hr) EGF.

(3) IGF-I group: animals infused with $400 \mu \mathrm{g} / \mathrm{rat} / \mathrm{day}$ hrIGF-I.

(4) EGF/IGF-I group: animals infused with $30 \mu \mathrm{g} / \mathrm{rat} /$ day hrEGF and $400 \mu \mathrm{g} / \mathrm{rat} /$ day hrIGF-I.

The growth factors were dissolved in $0 \cdot 1 \mathrm{M}$ acetic acid and delivered by osmotic minipumps (Model 2002, Alzet, Alza, Palo Alto, CA, USA) subcutaneously implanted on the back of each rat under light ether anesthesia. The infusion rate was $1 \mu \mathrm{l} / \mathrm{h}$ for 7 days.

Treatment was initiated at day 0 . The animals were weighed at days $0,2,4$, and 7 . At day 7 the animals were anesthetized with pentobarbital $(50 \mathrm{mg} / \mathrm{kg}$ i.p.). Nonfasting blood samples were collected from the retrobulbar plexus through heparinized capillary tubes under light ether anesthesia. On day 7 the animals were decapitated, the serum samples were kept at $-80{ }^{\circ} \mathrm{C}$ for later analysis. The left kidney and liver were removed, weighed and snap frozen in liquid nitrogen.

\section{Serum IGF-I}

Serum IGF-I was extracted using acid ethanol (30 $\mu \mathrm{l}$ serum and 750 ( $\mu \mathrm{l}$ acid ethanol) in order to determine total levels of circulating IGF-I as described previously (Daughaday et al. 1980). Serum extracts were diluted $1: 200$ in assay buffer $(40 \mathrm{mmol} / 1$ phosphate $\mathrm{pH} 8.0$, $0.6 \mathrm{mmol} / 1$ sodium merthiolate and $5 \%(\mathrm{w} / \mathrm{v})$ human serum albumin). IGF-I concentrations were analyzed by an in-house IGF-I RIA using a polyclonal rabbit antibody (Nichols Institute Diagnostics, San Capistrano, CA, USA) and rhIGF-I as standard (Amgen Biologicals, CA, USA, purchased from Amersham International, Amersham, Bucks, UK). Mono-iodinated rhIGF-I $\left({ }^{125} \mathrm{I}-\left(\mathrm{Tyr}^{31}\right)\right.$ IGF-I) was obtained from Novo Nordisk A/S Bagsvaerd, Denmark. The intra-assay and inter-assay coefficients of variation were $5 \%$ and $10 \%$ respectively.

\section{Serum IGFBPs}

SDS-PAGE and Western ligand blotting (WLB) analyses were executed according to the method of Hossenlopp (Hossenlopp et al. 1986) as described previously (Flyvbjerg et al. 1992).

\section{Gene-expression of IGF system genes ( $m R N A)$ in tissues}

Gene-expression of IGFBP 1-4 and -5 (renal) was measured by Northern blot analysis. Total RNA was extracted from kidney and liver samples by the guanidinium thiocyanate method (Chomczynski \& Sacchi 1987). Glyoxilated-RNA samples were electrophoresed in 1\% agarose gels submerged in $10 \mathrm{mM}$ sodium phosphate $(\mathrm{pH}$ $7 \cdot 2$ ) and transferred to nylon membranes (Hybond $\mathrm{N}^{+}$, Amersham, Hertogenbosch, The Netherlands). Filters were hybridized with $1-2 \times 10^{6}$ c.p.m. per $\mathrm{ml}$ of ${ }^{32} \mathrm{P}-$ labeled cDNA fragments encoding for each of the six mouse IGFBPs (Schuller et al. 1994) and 18S rRNA at $65^{\circ} \mathrm{C}$, according to the method of Church \& Gilbert (1984).

Gene expression of IGFBP-5 (hepatic), IGFBP-6, IGF-I, -II, IGF-I receptor, and the IGF-II/mannose-6phosphate (Man-6-P) receptor was below Northern blot detection levels and was measured by a semi-quantitative reverse transcriptase (RT) PCR approach using 18S internal standards (Ambion, Austin, TX, USA). One microgram of total RNA was reverse transcribed with 200 units of Moloney murine leukaemia virus (M-MLV) reverse transcriptase (Gibco BRL, Breda, The Netherlands) and primed with 3'-primers specific for the IGF-system genes. The RT reaction was carried out in $20 \mu \mathrm{l}$ (total volume) cDNA buffer $(75 \mathrm{mM} \mathrm{KCl}, 3 \mathrm{mM}$ $\mathrm{MgCl}_{2}, 50 \mathrm{mM}$ Tris-HCl, $\mathrm{pH}$ 8·3), $10 \mathrm{mM}$ DTT, $1 \mathrm{mM}$ of each deoxy-NTP, and $20 \mathrm{U}$ of RNAse guard (Pharmacia, Roosendaal, The Netherlands). The reaction mix was incubated for $1 \mathrm{~h}$ at $37^{\circ} \mathrm{C}$, heated to $95^{\circ} \mathrm{C}$ for $5 \mathrm{~min}$, and then diluted to $100 \mu \mathrm{l}$. The PCR reaction was carried out with $2 \mu \mathrm{l}$ of diluted RT mixture in PCR buffer (50 $\mathrm{mM} \mathrm{KCl}, 1.5 \mathrm{mM} \mathrm{MgCl}_{2}$, and $20 \mathrm{mM}$ Tris- $\mathrm{HCl}, \mathrm{pH}$ $8 \cdot 3), 25 \mathrm{pmol}$ forward and reverse primers and $1 \mathrm{U}$ of 
Table 1 (a) Body weight at the start (day 0) and end (day 7) of the study, liver weight at day 7 and kidney weight at day 7 (all mean \pm S.E.M., $n=8$ ) in adult female rats treated with placebo, EGF, IGF-I or EGF+IGF-I. (b) Liver and kidney weights, expressed as percentage of total body weight and related to placebo control animals

(a)

Body weight (g), day 0 Body weight $(\mathrm{g})$, day 7 Liver weight $(\mathrm{mg})$, day 7 Kidneys weight (mg), day 7

(b)

Liver

Kidneys

\begin{tabular}{l} 
Placebo control \\
\hline $190 \cdot 6 \pm 0 \cdot 4$ \\
$191 \cdot 7 \pm 2 \cdot 1$ \\
$3970 \pm 347$ \\
$1177 \pm 19$
\end{tabular}

\begin{tabular}{l} 
Placebo control \\
\hline 100 \\
100
\end{tabular}

\begin{tabular}{l} 
EGF \\
\hline $190 \cdot 5 \pm 0 \cdot 4$ \\
$191 \cdot 0 \pm 2 \cdot 3$ \\
$4528 \pm 591$ \\
$1213 \pm 16$ \\
EGF \\
\hline 114 \\
104
\end{tabular}

IGF-I

$\overline{190 \cdot 5} \pm 0 \cdot 4$
$196 \cdot 6 \pm 2 \cdot 7^{*}$
$4225 \pm 302$
$1456 \pm 15^{* * *}$

\section{IGF-I}

104

$121^{* * *}$
EGF+IGF-I

\begin{tabular}{l}
\hline $190 \cdot 3 \pm 0 \cdot 3$ \\
$202 \cdot 6 \pm 2 \cdot 2^{* * \#}$ \\
$4236 \pm 386$ \\
$1519 \pm 23^{* * *}$ \\
EGF+IGF \\
\hline 101 \\
$123^{* * *}$
\end{tabular}

${ }^{*} P=0 \cdot 04,{ }^{* *} P=0 \cdot 002,{ }^{* * *} P=<0 \cdot 001$, when compared with placebo controls ${ }^{\#} P=0.002$, when compared with the IGF-I infusion group.

Hi-Taq DNA Polymerase (Bioprobe Systems, France). PCR reactions were performed separately and the products analyzed on $1 \%$ agarose gel and transferred to nylon membranes (Hybond $\mathrm{N}^{+}$, Amersham). Filters were hybridized with $1-2 \times 10^{6}$ c.p.m. per ml ${ }^{32} \mathrm{P}$-labeled cDNA fragments encoding for the corresponding IGFsystem genes and $18 \mathrm{~S}$ rRNA. Oligonucleotide primers designed for the amplification were purchased from Pharmacia Biotech and were as follows: IGFBP-5: sense primer, 5'-TTGCCTCAACGAAAAGAGC-3'; antisense primer, 5'-AGAATCCTTTGCGGTCACA (size of corresponding PCR fragment: $377 \mathrm{bp}$ ). IGFBP-6: sense primer, 5'-GTCTACAGCCCTAAGTGCGCCCCAG3'; antisense primer, 5'-CACAGTTTGG-CACATAGA GCCCAC (size of corresponding PCR fragment: $345 \mathrm{bp}$ ). IGF-I: sense primer 5'-AAAATGACCGCACCTCC A-AC-3'; antisense primer, 5'-AGATCACAGCTCC GGAAGCA-3' (size of corresponding PCR fragment: 299 bp). IGF-II: sense primer 5'-GCCCCGGAGAGAC TCTGTGCG-3'; antisense primer, 5'-GCCCACGGGG TATCTGGGG-AA-3' (size of corresponding PCR fragment: $253 \mathrm{bp}$ ). IGF-I receptor: sense primer, 5'-GAG TACAACTACCGCTGCTGGAC-3'; antisense primer, 5'-AGGGGCCTTCACAGGGGA-TACA-3' (size of corresponding PCR fragment: 380 bp). IGF-II/Man-6-P receptor: sense primer, 5'-CCAGTTTCTTCTGCCAG CAAGGG-3'; antisense primer, 5'-GCTCCTCTCC AAG-AGCCTCTAC-3' (size of corresponding PCR fragment: $330 \mathrm{bp}$ ).

\section{Quantification}

Autoradiographs of ligand blots were scanned using a laser densitometer (Shimadzu model CS 90001 PC, Shimadzu Europe GmbH, Duisburg, Germany) and the relative densities of the bands expressed in arbitrary absorbency units per square millimeter $\left(\mathrm{AU} / \mathrm{mm}^{2}\right)$. Northern blots were scanned on a Phosphor Imager (Molecular
Dynamics, Sunnyvale, CA, USA) and quantified using ImageQuant software (Molecular Dynamics, Sunnyvale, CA, USA). All measured IGF-system results were expressed relative to $18 \mathrm{~S}$ rRNA levels, as mean \pm s.E.M., with $n$ indicating the number of animals studied.

\section{Statistical analysis}

Data were examined for distribution, variance homogeneity (F-test) and analyzed using Student's unpaired $t$-test if appropriate. Otherwise, the significance of difference was compared by one-way analysis of variance (ANOVA) followed by pair-wise comparisons with the least significant difference (LSD)-method. The interaction between EGF and IGF-I administration was compared by 2-way ANOVA followed by a regression model to assess the significance of the contribution of EGF and IGF-I. All data are expressed as mean \pm S.E.M., with $n$ indicating the number of rats studied and $P$-values less than $5 \%$ are considered significant.

\section{Results}

\section{Body weight}

In Table $1 \mathrm{~A}$ the body weights of the different study groups at the beginning (day 0) and end (day 7) of the experimental period are shown. The mean body weights on day 0 were between 190 and $191 \mathrm{~g}$ with no differences between the groups. At day 7, body weights of control animals and rats treated with EGF were identical. Rats treated with IGF-I or EGF/IGF-I significantly increased weight to $197 \pm 3 \mathrm{~g}(P=0.04$ day 0 versus day 7$)$ and $203 \pm 2 \mathrm{~g}(P=0 \cdot 002$ day 0 versus day 7$)$ respectively. In addition, the EGF/IGF-I treated group demonstrated a significantly increased weight gain when compared with the group that received EGF alone (EGF versus EGF/IGF-I, $P=0 \cdot 002)$. 
Table 2 Serum IGF-I and serum IGFBP levels (all mean \pm S.E.M., $n=8$ ) in adult female rats after 7 days of placebo, EGF, IGF-I or EGF+IGF-I treatment

\begin{tabular}{|c|c|c|c|c|}
\hline & Placebo control & EGF & IGF-I & EGF+ IGF-I \\
\hline IGF-I $(\mu / \mathrm{l})$ & $438 \pm 15$ & $396 \pm 25$ & $1537 \pm 92^{* * *}$ & $964 \pm 94^{\star \#}$ \\
\hline IGFBP-3 (AU/mm²) & $180 \cdot 4 \pm 12 \cdot 9$ & $78 \cdot 8 \pm 8 \cdot 6^{* * *}$ & $325 \cdot 8 \pm 17 \cdot 0^{* * *}$ & $213 \cdot 9 \pm 32 \cdot 1$ \\
\hline IGFBP-1 and $-2\left(\mathrm{AU} / \mathrm{mm}^{2}\right)$ & $36 \cdot 7 \pm 5 \cdot 8$ & $40 \cdot 6 \pm 5 \cdot 8$ & $90 \cdot 7 \pm 10 \cdot 7^{* *}$ & $112 \cdot 1 \pm 20 \cdot 0^{* *}$ \\
\hline IGFBP-4 (AU/mm²) & $22 \cdot 4 \pm 1 \cdot 7$ & $36 \cdot 9 \pm 3 \cdot 4^{*}$ & $19 \cdot 2 \pm 2 \cdot 2$ & $40 \cdot 7 \pm 5 \cdot 0^{* *}$ \\
\hline
\end{tabular}

${ }^{*} P \leq 0 \cdot 02,{ }^{* *} P \leq 0 \cdot 008,{ }^{* * *} P \leq 0 \cdot 001$, when compared with placebo controls.

${ }^{\#} P=0 \cdot 01$, when compared with the IGF-I infusion group.

\section{Liver and kidney weights}

At the end of the treatment the weights of the liver and kidneys were determined (Table $1 \mathrm{~A})$.

When compared with placebo control, infusion regimens did not demonstrate a significant effect on liver weight. In kidneys, EGF infusion alone did not result in an organ-specific weight increase while IGF-I and EGF/ IGF-I treatments significantly increased the weight to $121 \%(P<0.001)$ and $123 \%(P<0.001)$ of the control weight, respectively (Table $1 \mathrm{~B})$.

\section{Serum IGF-I}

By the end of the infusion period serum IGF-I levels were determined in all infusion groups (Table 2). In the EGF-treated group serum IGF-I levels were unchanged $(396 \pm 25 \mu \mathrm{g} / \mathrm{l})$. In the IGF-I treated group the IGF-I levels were significantly increased to $1537 \pm 92 \mu \mathrm{g} / 1$ $(P<0 \cdot 001)$. In the group treated with EGF/IGF-I IGF-I levels significantly increased to $964 \pm 94 \mu \mathrm{g} / 1(P=0 \cdot 01)$ However, compared with the IGF-I infusion group the increase in IGF-I was significantly lower in the EGF/ IGF-I group $(P=0 \cdot 01)$.

\section{Serum IGFBPs}

Using WLB four distinct bands were obtained. A double band at 42 and $38 \mathrm{kDa}$ represents IGFBP-3, a single band at $30 \mathrm{kDa}$ represents IGFBP-1 and -2 and a $24 \mathrm{kDa}$ band represents IGFBP-4 (as described previously) (Flyvbjerg et al. 1992).

In the EGF-treated group IGFBP-3 levels were significantly lowered to $44 \%$ of control values $(P<0 \cdot 001)$ whereas in the IGF-I treated group IGFBP-3 levels were significantly increased to $181 \%$ of control values $(P<0 \cdot 001)$. In the EGF/IGF-I-treated group the circulatory IGFBP-3 values remained unchanged (Table 2). Circulating $30 \mathrm{kDa}$ IGFBPs (IGFBP-1 and -2) were unchanged in the EGF treatment group. However, in the IGF-I and EGF/IGF-I groups the $30 \mathrm{kDa}$ IGFBPs (IGFBP-1 and -2) were significantly increased to $247 \%$ and $305 \%$ of control values (both $P=0 \cdot 007$ ). IGF-I infusion did not significantly modify IGFBP-4 levels, whereas
EGF and EGF/IGF-I infusion demonstrated significantly increased IGFBP-4 levels (165\% and 182\% of control values; $P=0.02$ and $P=0.008$ respectively) (Table 2 ).

\section{Hepatic IGF system expression}

Compared with the mRNA expression in control rats, EGF infusion did not significantly modify hepatic IGF system mRNA levels (Fig. 1).

IGF-I-infused animals demonstrated significantly increased hepatic IGFBP-1 $(P=0.03)$ and IGFBP-3 $(P=0 \cdot 001)$ mRNA levels when compared with placebo infused rats (Fig. 1A), whereas IGFBP-5 mRNA levels were significantly decreased in the IGF-I infusion group $(P=0.05) \quad$ (Fig. 1B). IGFBP-5 mRNA levels in the EGF/IGF-I infusion group were the result of a significant interaction between EGF and IGF-I that, however, could not be significantly attributed to EGF and/or IGF-I.

In the EGF/IGF-I infusion group, hepatic IGFBP-1, -2 and -3 mRNA levels were significantly increased $(P=0.03, P=0.01$ and $P=0.001$ respectively) (Fig. 1). IGFBP-2 mRNA levels in the EGF/IGF-I infusion group were the result of a significant interaction between EGF and IGF-I that could be significantly attributed EGF $(P<0 \cdot 001)$ and IGF-I $(P<0 \cdot 02)$.

Hepatic IGF-II and IGF-I receptor mRNA could not be reliably quantified in any of the groups.

\section{Renal IGF system expression}

Compared with the expression levels in control rats, EGF infusion did not change renal mRNA levels of most of the IGF system genes. Only IGFBP-4 demonstrated significantly increased $(P=0.03)$ whereas IGFBP-6 demonstrated significantly decreased $(P=0.03)$ renal mRNA levels (Fig. 2A and B). IGF-I-infused animals demonstrated significantly decreased renal IGFBP-6 mRNA levels $(P=0 \cdot 001)$ (Fig. 2B).

In the EGF/IGF-I infusion group, the renal IGFBP-4 mRNA levels were significantly increased $(P=0 \cdot 05)$ (Fig. $2 \mathrm{~A})$, whereas renal IGFBP-6 and IGF-II/Man-6-P receptor mRNA levels were significantly decreased $(P=0.02$ and $P=0 \cdot 01$ respectively) (Fig. $2 \mathrm{~B}$ ). IGFBP-6 mRNA 

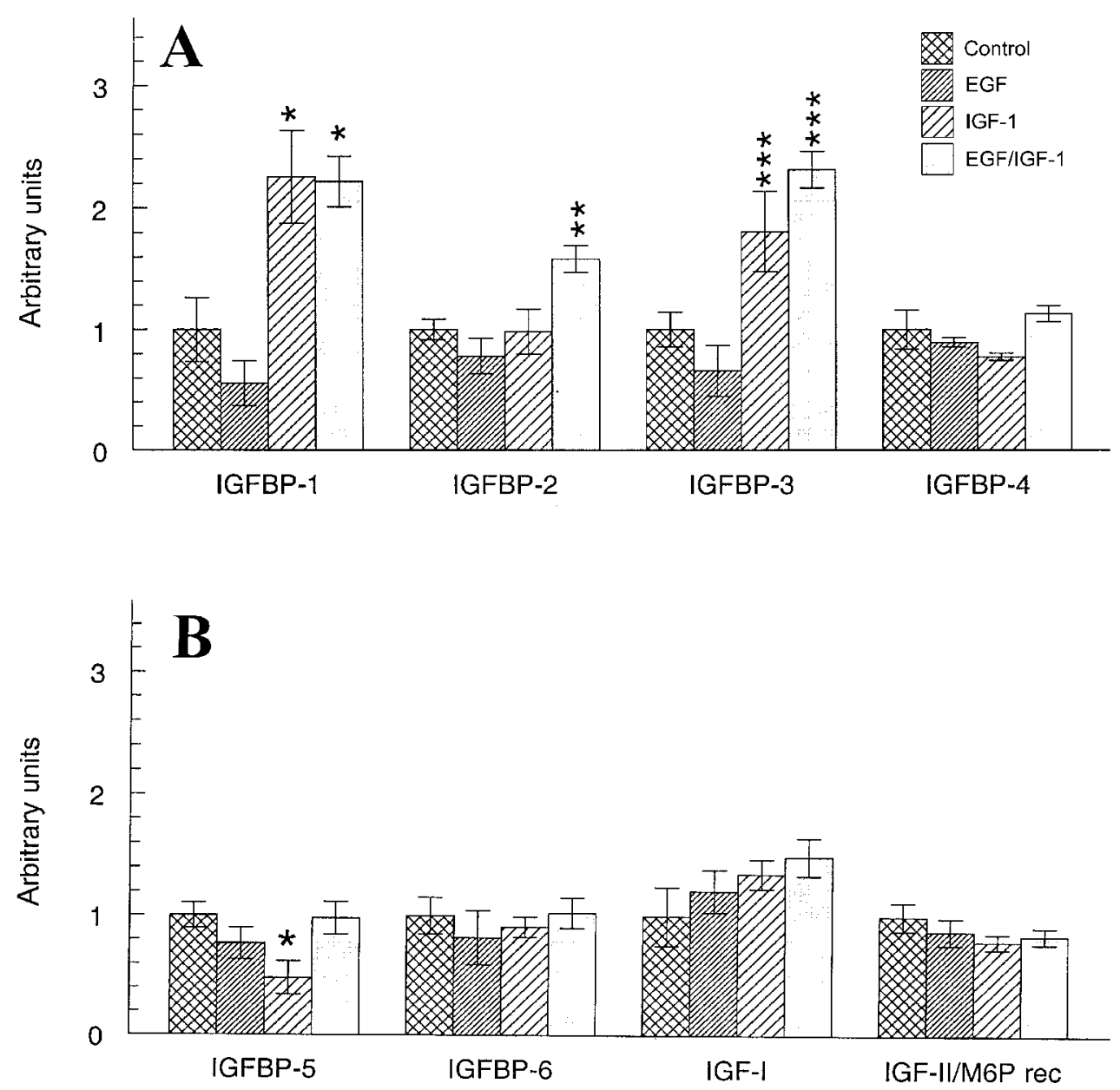

Figure 1 (A) Hepatic IGFBP-1, -2, -3 and -4 mRNA levels in young adult female rats, infused for 7 days with acetic acid (placebo control), $30 \mu \mathrm{g} / \mathrm{kg} /$ day EGF, $400 \mu \mathrm{g} / \mathrm{kg} /$ day IGF-I and $30 \mu \mathrm{g} / \mathrm{kg} /$ day EGF $+400 \mu \mathrm{g} / \mathrm{kg} / \mathrm{day}$ IGF-I. Values are based on quantitations of Northern blots where each lane contained $20 \mu \mathrm{g}$ of total RNA and was compensated for RNA loading differences. Values are represented as means \pm S.E.M. $(n=8)$ and expressed relative to placebo control. ${ }^{*} P=0 \cdot 03,{ }^{*} P=0 \cdot 01,{ }^{* *} P=0 \cdot 001$, statistical significance level between the indicated group and the placebo control. (B) Hepatic IGFBP-5, -6, IGF-I and IGF-II/Man-6-P receptor mRNA levels in young adult female rats, infused for 7 days with acetic acid (placebo control), $30 \mu \mathrm{g} / \mathrm{kg} /$ day EGF, $400 \mu \mathrm{g} / \mathrm{kg} /$ day IGF-I and $30 \mu \mathrm{g} / \mathrm{kg} /$ day EGF $+400 \mu \mathrm{g} / \mathrm{kg} /$ day IGF-I. Values represent the quantified outcome of RT-PCR reactions, compensated for differences in efficiency and the amount of starting material. Values are represented as means \pm S.E.M. $(n=8)$ and expressed relative to placebo control. ${ }^{*} P=0 \cdot 05$, statistical significance level between the indicated group and the placebo control.

levels in the EGF/IGF-I infusion group were the result of a significant interaction between EGF and IGF-I that could be significantly attributed to EGF $(P=0.04)$ and IGF-I $(P=0 \cdot 006)$.

Renal IGF-I and IGF-II mRNA could not be reliably quantified in any of the groups.

\section{Discussion}

In the present study we investigated the effects of shortterm systemic treatment with EGF and/or IGF-I on growth parameters and hepatic and renal expression of the IGF system genes in young adult female rats.

EGF infusion did not show any effect on body weight gain. This is in agreement with our earlier EGF infusion study in young adult male rats where EGF administration for 4 weeks $(400 \mu \mathrm{g} / \mathrm{kg} /$ day $)$, did not significantly change body weight gain (Frystyk et al. 1996). In newborn animals, EGF treatment (doses $50-1000 \mu \mathrm{g} / \mathrm{kg} /$ day) results in retarded organ and body growth (Hoath et al. 1988). This growth retardation was most prominent when EGF was applied directly after birth and persisted until weaning (Hoath 1986). EGF is normally present in very 

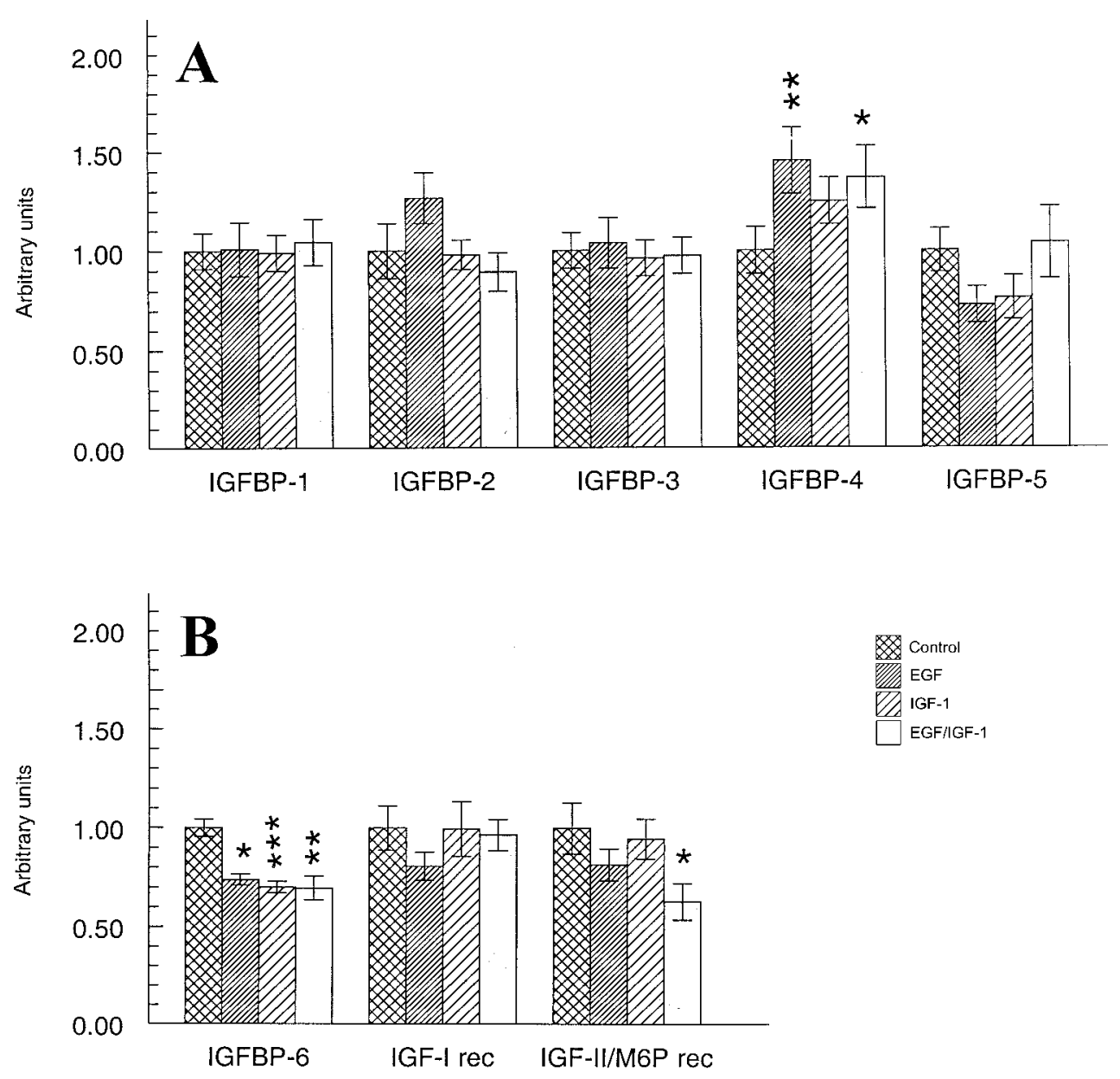

Figure 2 (A) Kidney IGFBP-1, -2, -3, -4 and -5 mRNA levels in young adult female rats, infused for 7 days with acetic acid (placebo control), $30 \mu \mathrm{g} / \mathrm{kg} /$ day EGF, $400 \mu \mathrm{g} / \mathrm{kg} /$ day IGF-I and $30 \mu \mathrm{g} / \mathrm{kg} /$ day EGF+ $400 \mu \mathrm{g} / \mathrm{kg} /$ day IGF-I. Values are based on quantitations of Northern blots where each lane contained $20 \mu \mathrm{g}$ of total RNA and was compensated for RNA loading differences. Values are represented as means \pm S.E.M. $(n=8)$ and expressed relative to placebo control. ${ }^{*} P=0 \cdot 05,{ }^{*} P=0 \cdot 03$, statistical significance level between the indicated group and the placebo control. (B) Kidney IGFBP-6, IGF-I receptor and IGF-II/Man-6-P receptor mRNA levels in young adult female rats, infused for 7 days with acetic acid (placebo control), $30 \mu \mathrm{g} / \mathrm{kg} /$ day EGF, $400 \mu \mathrm{g} / \mathrm{kg} /$ day IGF-I and $30 \mu \mathrm{g} / \mathrm{kg} /$ day EGF $+400 \mu \mathrm{g} / \mathrm{kg} /$ day IGF-I. Values represent the quantitated outcome of RT-PCR reactions, compensated for differences in efficiency and the amount of starting material. Values are represented as means \pm S.E.M. $(n=8)$ and expressed relative to placebo control. ${ }^{*} P=0 \cdot 02,{ }^{* *} P=0 \cdot 01,{ }^{* *} P=0 \cdot 005$, statistical significance level between the indicated group and the placebo control.

low $(0 \cdot 1<2 \mu \mathrm{g} / \mathrm{l})$ quantities in circulation (Nexø et al. 1992). Systemic administration at the doses used in these studies, therefore, represents a pharmacological situation.

In contrast to EGF infusion, IGF-I infusion resulted in a significantly increased body weight gain. This is in agreement with an earlier study where $240 \mu \mathrm{g} / \mathrm{rat} / \mathrm{day}$ IGF-I was infused for 14 days in 6-week-old female rats (van Neck et al. 1997). EGF/IGF-I infusion also resulted in a significantly increased body weight gain. However, weight gain in this group did not significantly differ from the IGF-I infusion group.
Liver weight was not increased in any of the growth factor treatment regimens. This is in agreement with earlier studies (Frystyk et al. 1996, van Neck et al. 1997). In contrast, kidney weight was significantly increased in the IGF-I and in the EGF/IGF-I treatment groups but not by EGF treatment alone. The observed effect of IGF-I infusion on kidney weight is consistent with earlier findings (Gruaz et al. 1997, van Neck et al. 1997), as is the ineffectiveness of EGF on kidney growth (Frystyk et al. 1996). This is in contrast to the findings of Breider et al. (1996) who infused male and female animals with 
$100 \mu \mathrm{g} / \mathrm{kg} /$ day EGF for 4 weeks and observed both liver and kidney enlargement. Interestingly, in this study, kidney enlargement only was observed in female animals.

The effects of systemic EGF administration have been extensively studied in neonatal rats. In newborn animals EGF administration reduced the circulatory IGF-I levels but increased the mRNA and protein expression of IGFBP-1 (Murray et al. 1993). Older animals demonstrated strongly diminished responses to EGF infusion. In our study, EGF infusion did not affect the $30 \mathrm{kDa}$ IGFBPs (IGFBP-1 and -2) and the hepatic mRNA expression did not change. In contrast, treatment with EGF/IGF-I increased the $30 \mathrm{kDa}$ protein band and the hepatic IGFBP-1 and -2 mRNA expression. IGFBP-4 was increased in both the EGF and EGF/IGF-I infusion groups whereas the corresponding hepatic mRNA levels were unchanged. EGF infusion reduced IGFBP-3 levels. This was also observed in previous studies (Frystyk et al. 1996, Vinter-Jensen et al. 1996). In addition, the EGF/ IGF-I infusion group also revealed reduced IGFBP-3 levels when compared with the IGF-I infusion group, however, with unchanged hepatic IGFBP-3 mRNA levels. This is in contrast to in vitro studies where a 5 -fold reduction in IGFBP-3 mRNA was demonstrated in cultured keratinocytes by treatment with EGF (Wraight \& Werther 1995, Edmondson et al. 1999). In our in vivo experiment, a post-transcriptional event probably underlies the observed decrease in IGFBP-3, as hepatic IGFBP-3 mRNA was not significantly decreased in the EGF and EGF/IGF-I infusion groups. To test the effect of EGF on IGFBP-3 stability, ${ }^{125}$ I-IGFBP-3 was incubated with different doses of EGF ranging from 0.001 to $500 \mu \mathrm{g} / \mathrm{ml}$. EGF had no effect on IGFBP-3 proteolysis in vitro excluding a direct IGFBP-3 proteolytic effect (data not shown). EGF infusion did not influence the hepatic mRNA levels of the other members of the IGF-system. Barreca described a dose-dependent stimulation of IGF-I secretion in cultured liver cells, already detectable at a concentration of $30 \mu \mathrm{g} / 1$ (Barreca et al. 1992). In our rat in vivo experiments, however, the EGF infusion group did not show a stimulatory effect on circulatory IGF-I levels, nor did EGF infusion significantly increase hepatic IGF-I mRNA expression.

In the IGF-I infusion group, circulatory levels of the $30 \mathrm{kDa}$ IGFBPs (IGFBP-1 and -2) and IGFBP-3 were significantly increased. These changes were reflected by corresponding changes in the hepatic mRNA profiles of IGFBP-1 and -3. In a previous study, IGF-I infusion for 14 days also upregulated hepatic IGFBP-3 mRNA levels (van Neck et al. 1997). Compared with the IGF-I infusion group, IGFBP-3 levels in the EGF/IGF-I infusion group were significantly decreased. Decreased IGFBP-3 levels may result in a release of free, biodegradable IGF-I which may explain the decreased circulating pool of IGF-I as observed in the EGF/IGF-I group.
In the IGF-I infusion group, circulatory IGF-I levels were increased 3-fold, achieving levels similar to those measured in an earlier IGF-I infusion study (van Neck et al. 1997). In the EGF/IGF-I infusion group, circulatory IGF-I levels were significantly reduced. As identical amounts of IGF-I were infused in both the EGF/IGF-I and IGF-I group, EGF, therefore, seemed to decrease the amount of circulatory IGF-I without affecting its mRNA level.

In kidney, only IGFBP-6 mRNA levels were lower in the IGF-I treatment group. IGF-I infusion did not influence the local expression of the other IGF-system members despite its pronounced effects on kidney growth.

To our knowledge the present study is the first to investigate the very complex interaction or cross-talk between the EGF and the IGF-system in vivo. IGF-I and EGF/IGF-I infusions significantly increased circulatory IGF-I but had no effect on hepatic IGF-I levels. Kidney weight was also significantly increased in these groups. EGF infusion lowered circulatory IGFBP-3 without an effect on hepatic IGFBP-3 mRNA levels.

\section{Acknowledgements}

We would like to thank Karen Mathiassen, Kirsten Nyborg and Nina Rosenqvist for excellent technical assistance. We are grateful to Ciba-Geigy (Basle, Switzerland) and Upstate Biotechnology (New York, USA) for the generous gift of IGF-I and EGF respectively. This work was supported by grants from the Sophia Foundation for Medical Research, the Dutch Diabetes Association, Novo-Nordisk Insulin Laboratories, the Danish Diabetes Association, the Danish Kidney Foundation, the Danish Medical Research Council (\#9700592), the Ruth König Peterson Foundation, the Novo Foundation, the Nordic Insulin Foundation, the Aage Louis-Hansen Memorial Foundation, the Eva and Henry Fraenkels Memorial Foundation and the Aarhus University-Novo Nordisk Center for Research in Growth and Regeneration (\#9600822).

\section{References}

Barreca A, Voci A, Minuto F, de Marchis M, Cecchelli E, Fugassa E, Giordano G \& Gallo G 1992 Effect of epidermal growth factor on insulin-like growth factor-I (IGF- I) and IGF-binding protein synthesis by adult rat hepatocytes. Molecular and Cellular Endocrinology 84 119-126.

Baxter RC, Binoux MA, Clemmons DR, Conover CA, Drop SL, Holly JM, Mohan S, Oh Y \& Rosenfeld RG 1998 Recommendations for nomenclature of the insulin-like growth factor binding protein superfamily. Endocrinology 1394036.

Bonassar LJ \& Trippel SB 1997 Interaction of epidermal growth factor and insulin-like growth factor-I in the regulation of growth plate chondrocytes. Experimental Cell Research 234 1-6. 
Breider MA, Bleavins MR, Reindel JF, Gough AW \& de la Iglesia FA 1996 Cellular hyperplasia in rats following continuous intravenous infusion of recombinant human epidermal growth factor. Veterinary Pathology 33 184-194.

Bujia J, Holly A, Schilling V, Negri B, Pitzke P \& Schulz P 1993 Aberrant expression of epidermal growth factor receptor in aural cholesteatoma. Laryngoscope 103 326-329.

Chomczynski P \& Sacchi N 1987 Single-step method of RNA isolation by acid guanidinium thiocyanate-phenol-chloroform extraction. Analytical Biochemistry 162 156-159.

Church GM \& Gilbert W 1984 Genomic sequencing. Proceedings of the National Academy of Sciences of the USA 81 1991-1995.

Daughaday WH, Mariz IK \& Blethen SL 1980 Inhibition of access of bound somatomedin to membrane receptor and immunobinding sites: a comparison of radioreceptor and radioimmunoassay of somatomedin in native and acid-ethanol-extracted serum. Journal of Clinical Endocrinology and Metabolism 51 781-788.

Edmondson SR, Murashita MM, Russo VC, Wraight CJ \& Werther GA 1999 Expression of insulin-like growth factor binding protein-3 (IGFBP-3) in human keratinocytes is regulated by EGF and TGF $\beta 1$. Journal of Cellular Physiology 179 201-207.

Fisher DA, Salido EC \& Barajas L 1989 Epidermal growth factor and the kidney. Annual Review of Physiology 51 67-80.

Flyvbjerg A, Kessler U, Dorka B, Funk B, Ørskov H \& Kiess W 1992 Transient increase in renal insulin-like growth factor binding proteins during initial kidney hypertrophy in experimental diabetes in rats. Diabetologia 35 589-593.

Frystyk J, Vinter-Jensen L, Skjaerbaek C \& Flyvbjerg A 1996 The effect of epidermal growth factor on circulating levels of free and total IGF-I and IGF-binding proteins in adult rats. Growth Regulation 6 48-54.

Gruaz NM, d'Alleves V, Charnay Y, Skottner A, Ekvarn S, Fryklund L \& Aubert ML 1997 Effects of constant infusion with insulin-like growth factor-I (IGF-I) to immature female rats on body weight gain, tissue growth and sexual function. Evidence that such treatment does not affect sexual maturation of fertility. Endocrine Journal 6 11-19.

Hoath SB 1986 Treatment of the neonatal rat with epidermal growth factor: differences in time and organ response. Pediatric Research 20 468-472.

Hoath SB, Pickens WL \& Donnelly MM 1988 Epidermal growth factor-induced growth retardation in the newborn rat: quantitation and relation to changes in skin temperature and viscoelasticity. Growth, Development and Aging $\mathbf{5 2}$ 77-83.

Hossenlopp P, Seurin D, Segovia-Quinson B, Hardouin S \& Binoux M 1986 Analysis of serum insulin-like growth factor binding proteins using Western blotting: use of the method for titration of the binding proteins and competitive binding studies. Analytical Biochemistry 154 138-143.

Kelley KM, Oh Y, Gargosky SE, Gucev Z, Matsumoto T, Hwa V, Ng L, Simpson DM \& Rosenfeld RG 1996 Insulin-like growth factor-binding proteins (IGFBPs) and their regulatory dynamics. International Journal of Biochemistry and Cell Biology 28 619-637.

Krane JF, Murphy DP, Carter DM \& Krueger JG 1991 Synergistic effects of epidermal growth factor (EGF) and insulin-like growth factor I/somatomedin C (IGF-I) on keratinocyte proliferation may be mediated by IGF-I transmodulation of the EGF receptor. Journal of Investigative Dermatology 96 419-424.

Miettinen PJ 1997 Epidermal growth factor receptor in mice and men - any applications to clinical practice? Annual Review of Medicine 29 531-534.

Murakami Y, Nagata H, Shizukuishi S, Nakashima K, Okawa T, Takigawa M \& Tsunemitsu A 1994 Histatin as a synergistic stimulator with epidermal growth factor of rabbit chondrocyte proliferation. Biochemical and Biophysical Research Communications 198 274-280.

Murray MA, Dickson BA, Smith EP, Hoath SB \& Chernausek SD 1993 Epidermal growth factor stimulates insulin-like growth factor-binding protein-1 expression in the neonatal rat. Endocrinology 133 159-165

van Neck JW, Flyvbjerg A, Schuller AG, Rosato RR, Groffen CA, van Kleffens M, Lindenbergh-Kortleve DJ, Dørup I \& Drop SL 1997 IGF, type I IGF receptor and IGF-binding protein mRNA expression in kidney and liver of potassium-depleted and normal rats infused with IGF-I. Journal of Molecular Endocrinology 19 $59-66$.

Nexø E, Jorgensen E \& Hansen MR 1992 Human epidermal growth factor - on molecular forms present in urine and blood. Regulatory Peptides 42 75-84.

Rogers SA, Miller SB \& Hammerman MR 1991 Insulin-like growth factor I gene expression in isolated rat renal collecting duct is stimulated by epidermal growth factor. Journal of Clinical Investigation 87 347-351.

Schuller AG, Groffen C, van Neck JW, Zwarthoff EC \& Drop SL 1994 cDNA cloning and mRNA expression of the six mouse insulin-like growth factor binding proteins. Molecular and Cellular Endocrinology 104 57-66.

Vinter-Jensen L, Juhl CO, Frystyk J, Dajani EZ, Oksbjerg N \& Flyvbjerg A 1996 The effect of epidermal growth factor on circulating levels of IGF and IGF-binding proteins in adult Goettingen minipigs. Journal of Endocrinology 151 401-407.

Wraight CJ \& Werther GA 1995 Insulin-like growth factor-I and epidermal growth factor regulate insulin-like growth factor binding protein-3 (IGFBP-3) in the human keratinocyte cell line HaCaT. Journal of Investigative Dermatology 105 602-607.

Received 27 May 1999

Revised manuscript received 3 November 1999 Accepted 23 November 1999 